\title{
Chapter 13 \\ What Influences Rural Poor in India \\ to Refill Their LPG?
}

\author{
Liya Thomas, Raksha Balakrishna, Rahul Chaturvedi, \\ Pranab Mukhopadhyay, and Rucha Ghate
}

\section{Key Messages}

- Rural income generation schemes, female literacy, positively influence LPG refills.

- While male work force participation increases LPG refills, female workforce does not.

- Vicinity to forest has heterogeneous effects depending on type of forest.

\subsection{Introduction}

Under the Nationally Determined Contributions (NDC) in the Paris Agreement (2015) India has committed to reduce emission intensity by 33-35\%; increase the share of non-fossil-based energy to $40 \%$; and improve its forest and tree cover to create an additional carbon sink of 2.5-3 GT- $\mathrm{CO}_{2} \mathrm{e}$ (UNFCCC, 2018). Meeting these

L. Thomas $\cdot$ R. Balakrishna $\cdot$ R. Chaturvedi $\cdot$ R. Ghate

Foundation for Ecological Security, Anand, India

L. Thomas

e-mail: liyabensy@gmail.com

R. Balakrishna

e-mail: raksha.balakrishna@gmail.com

R. Chaturvedi

e-mail: rahul.chaturvedi@fes.org.in

R. Ghate

e-mail: rucha@fes.org.in

P. Mukhopadhyay ( $\square)$

Goa Business School, Goa University, Taleigao Plateau, Goa, India

e-mail:pm@unigoa.ac.in 
carbon-mitigation commitments requires the adoption of cleaner and more efficient alternatives. Liquefied petroleum gas (LPG) and natural gas have been internationally recommended as a mitigation measure to reduce black carbon emissions (IPCC, 2018). A push towards cleaner cooking technologies like LPG would help in achieving targets under five of the 17 SDGs, namely SDG 3-Good health and well-being; SDG 5-Gender equality; SDG 7-Affordable and clean energy; SDG 13-Climate action and SDG 15-Life on land (Rosenthal et al., 2018). This chapter examines the impact of rural employment generation programmes along with various socio-economic and local environmental factors on LPG use.

LPG is a naturally occurring, unavoidable by-product of oil and natural gas extraction and crude oil refining. Earlier, LPG was vented or flared at sites, wasting valuable fuel and spewing black carbon into the atmosphere (Van Leeuwen et al., 2017). Utilizing it instead has been recognized as beneficial for both environment and human health in comparison with alternatives such as solid biomass fuels as it releases lower levels of black carbon and methane (Bruce et al., 2017).

A 2016 report states that as many as 819 million people (nearly 60\% of the population) in India use traditional biomass such as fuelwood, cow dung, and coal, for their daily cooking needs, sourced primarily from nearby forests and wooded areas (IEA, 2016). Widespread use of these fuels poses serious risk to both human and environmental health (Junaid et al., 2018). Incomplete combustion of the fuels on inefficient stoves, and other devices used for cooking, lighting and heating, leads to household air pollution (HAP). High levels of HAP include health-damaging pollutants such as fine particles and carbon monoxide and contribute to about 4-6\% of the burden of disease in India (Smith, 2000). Since women and children spend most time at home, they are the most adversely affected (Kankaria et al., 2014; Smith \& Sagar, 2014). Mitigating the ill-effects of HAP is crucial not just to achieve targets of improved health (SDG 3) but also gender equality (SDG 5). In addition, shifting to cleaner fuels like LPG reduces the burden of fuel wood collection and reduces cooking time, thus allowing for empowerment of women (Rosenthal et al., 2018). Studies have estimated that HAP contributes to between 22 and 52\% of ambient PM2.5 exposure in India also adding to the climate crisis (Conibear et al., 2018).

Burning fuelwood emits climate pollutants such as black carbon, methane, carbon monoxide and other ozone-depleting gases. In South Asia, over half of black carbon comes from cook stoves, disrupting the monsoon and expediting the HimalayanTibetan glacier melting (Chung et al., 2012). In rural areas of developing countries, emission from biomass-based cooking alone was $49.0 \mathrm{GtCO}_{2}$-eq (recorded in 2004) (IPCC, 2007). Though LPG has been criticized as a fossil fuel, till such time as there are renewable alternatives, LPG could be promoted as the available cleaner solution with the potential of reducing emissions from $49.0 \mathrm{GtCO}_{2}$-eq to 0.70 . This would directly help meet NDC commitments of reduced emission and targets under SDG 3 (Good health and well-being) and SDG 13 (Climate action).

In addition, fuelwood extraction for fuel and energy is also a major contributor to deforestation and threatens the health of forests and other wooded areas. Global estimates indicate that about $30 \%$ of wood fuel harvesting is unsustainable (Bailis et al., 2015). In 2010-2011, the annual fuelwood consumption by India was 216.4 
million tonnes per year (FSI, 2011). By protecting forests from fuelwood and charcoal extraction, LPG use could reduce the pressure on local resources and thereby enable carbon sequestration.

\subsubsection{Policy Evolution Towards Cleaner Cooking: LPG}

The rural poor in South Asia are heavily dependent on natural resources and thus directly influenced by extreme weather events (IPCC, 2014). In the wake of the warming temperature and decreasing precipitation, studies have projected an increased risk of climate disasters in India (Bisht et al., 2019). At the household level, this would translate to reduced availability of food, fodder, water and fuelwood in the short term and ecological and socio-economic consequences in the long term. When faced with such shortages, disadvantaged groups are likely to be most affected. In this context, adapting and promoting innovative cleaner energy sources such as LPG could potentially increase the resilience of rural communities to changing climate. Shamin and Haque (2022, Chap. 14 this volume) examine a similar question with respect to the adoption of solar systems in Bangladesh.

Realizing this, India has made many attempts to introduce improved cooking technologies that provide "triple benefits"-reduction in HAP and time-saving for households (health benefit), reduction in forest dependence (local environmental benefit) and reduced emission of carbon (global benefit) (Bhojvaid et al., 2014; Jeuland \& Pattanayak, 2012). Since 2009, the government has attempted to promote the use of LPG as a fuel choice for households in remote and rural areas.

Starting with the Rajiv Gandhi Gramin LPG Vitarak Yojana (RGGLVY) (Sankhyayan \& Dasgupta, 2019), the scheme evolved into the Pradhan Mantri Ujjwala Yojana (PMUY) in May 2016. This intervention aimed at bringing the benefit of efficient and low-emission fuel options to households that could not afford it because of their income status (Dabadge et al., 2018). The initial aim was to provide 50 million women belonging to poor (below the poverty line, BPL) families with gas (liquefied petroleum gas, LPG) connections. The scheme aimed to provide financial support for new LPG connection (installation).

Apart from RGGLVY and PMUY, the government has introduced other schemes like Pahal and complementing campaigns like "Give it Up" that have been crucial in ensuring that subsidies for LPG reach those who need them most (Gould \& Urpelainen, 2018). While Pahal Consumers Scheme, launched in June 2013 aimed at directly transferring LPG subsidies to the bank accounts of consumers, the 2015 "Give it Up" scheme focused on motivating LPG consumers who can afford to pay full price for the cylinders to give up the LPG subsidy voluntarily.

Over the past decade, there has been steady progress towards the adoption of clean fuels in India. The number of LPG connections in the country has more than doubled, from 106 million households in 2009 to 263 million in 2018; total household consumption of LPG has increased from 10.6 million tonnes to 20.4 million tonnes during the same period (PPAC, 2018). With a push towards the adoption and use of 
cleaner cooking fuels, nearly $90 \%$ of Indian households now have LPG connections, making it the world's second-largest consumer of LPG (PPAC, 2019). However, sustained use of this fuel remains a challenge (Kar et al., 2019).

\subsubsection{Factors Limiting Sustained Use of LPG}

While there is general acceptance that the adoption of cleaner fuels like LPG has the potential to deliver health, social and environmental benefits including positive climate impacts in the short term, there has been mixed success on their sustained use despite state-subsidized efforts (Bruce et al., 2017; Rosenthal et al., 2018). Earlier studies suggest that there is a wide heterogeneity of factors influencing its use (Jain et al., 2018; Kumar et al., 2017; Singh et al., 2017). This includes; price (Sankhyayan \& Dasgupta, 2019), women's participation in household decision-making (Gould \& Urpelainen, 2018), seasonality (Kar et al., 2019) and household characteristics like house type and household size, and ease of access (Giri \& Aadil, 2018).

Households with irregular income and easy accessibility to biomass fuel are less likely to use LPG for all their cooking needs (Mani et al., 2020). Forested areas and shared land resources in and around villages have been the primary source of this fuelwood (Pandey, 2002). Households that have traditionally depended on fuelwood for cooking purposes continue to do so, especially for heating water and large-scale cooking. In rural areas, the annual average fuelwood consumption per capita was estimated at $796 \mathrm{~kg}$ (Pandey, 2002). With continued population growth, demand for fuelwood is only likely to grow in the future resulting in the degradation of the forests in the vicinity of villages and the formation of barren lands. With improved access to LPG connections, households have started practising fuel stacking, wherein they stack both traditional biomasses such as fuelwood along with LPG, to meet requirements. However, in Bangladesh, Bari, Haque and Khan (2022, Chap. 14 of this volume) found that better supply of LPG reduced forest dependence of rural migrant communities.

There is a recognized need for a policy push to offset the use of biomass fuel by cleaner cooking technologies such as LPG. This shift could help India to meet NDC commitments as well as five of the Sustainable Development Goals, 2030.

\subsubsection{MGNREGA a "Window of Opportunity" to Improve LPG Use?}

Affordability has been recognized as one of the crucial barriers in LPG use (Khandker et al., 2012). This can be ensured either by making money available to rural households through more work and better wages or by extending higher subsidies. In the long run, increasing the disposable income of rural households to buy refills is 
more sustainable than providing subsidies. We examine the potential of the Mahatma Gandhi National Rural Employment Guarantee Act (MGNREGA), which guarantees 100 days of wage employment per year to rural households, in influencing LPG use in India. We expect that a district that has a higher per capita MGNREGA expenditure presumably has employed more people and/or for longer days and hence gives the rural poor of that district a better income status. It is contended that by utilizing the otherwise untapped labour potential in rural areas, the programme effectively increases the purchasing power of rural households.

While testing this expectation, the chapter also examines other socio-economic and environmental factors that could influence LPG use in India. LPG use can be inferred not from the number of connections but from the frequency of refills. We, therefore, test the relationship between the frequency of refills and various socioeconomic and environmental factors.

In rural areas, households still primarily depend on rain-fed agriculture. Therefore, rainfall in a district would strongly predict the agricultural income of a region, ceteris paribus (Gadgil \& Gadgil, 2006; Krishna Kumar et al., 2004; University of East Anglia Climatic Research Unit (CRU) et al., 2019). Supply and cost drive fuel choice, i.e. village communities who live in the proximity of forests are likely to choose fuelwood over LPG as the relative shadow price of fuelwood is much lower than LPG. The economic status of households would be reflected by the extent of poverty in the district. While poverty rates are a direct way to understand the income distribution of a region, the economic well-being can also be gauged by the participation of the population in the workforce. This would directly indicate income generation opportunities - we expect that the higher the workforce participation rate in a district, the better off the households of that district due to available income from employment.

Given the demographic structure of Indian societies, women's empowerment through education could have significant implications for family decision-making (Sen, 2000) which includes decisions on expenditure on fuel and women's health. Education is a known tool for empowerment within and outside the household (Walker, 2005). People (especially women) of a more literate society are likely to choose cleaner fuel even if it costs more as they would value their health and make more informed choices. Economic deprivation in India is closely linked to social categories. Scheduled Tribes (ST) and Scheduled Castes (SC) have, for long, been known to be historically deprived (Deshpande, 2011). We, therefore, use SC and ST proportions in rural populations to understand the extent of deprivation at the district level.

\subsection{Material and Methods}

We have used data available from government sources on LPG connections and refills (PMUY, 2018); MGNREGA expenditure for the year 2017-2018; forest survey data (FSI, 2019); district-level rainfall data (IMD, 2015, 2016, 2017, 2018; University Of East Anglia Climatic Research Unit (CRU) et al., 2019); poverty data (Chaudhuri \& 
Gupta, 2009); and demographic data (Census, 2011). After matching LPG data with all the above data, we were left with complete data for 582 districts across 29 states and three union territories.

We use a formal regression model for our analysis. Our dependent variable is the proportion of LPG refills to the number of LPG connections registered under the PMUY scheme in each district. This we have treated as an indicator of LPG adoption. We anticipate, as stated above, that this would be dependent on multiple factors.

LPG refills in $2019=f$ (amount of per capita expenditure per capita on MGNREGA in 2018 [preceding year], the extent of rainfall in 2018 [preceding year], rural female literacy rate, the proportion of SC and ST in rural areas, the proportion of the rural population in the workforce, percentage of poor in rural districts and extent of different types of forests)

The specific model using the ordinary least squares (OLS) multiple regression method is discussed below.

$$
\begin{aligned}
Y_{i}= & \beta_{0}+\beta_{1} X_{1 i}+\beta_{2} X_{2 i}+\beta_{3} X_{3 i}+\beta_{4} X_{4 i}+\beta_{5} X_{5 i} \\
& +\beta_{6} X_{6 i}+\beta_{7} X_{7 i}+\beta_{8} X_{8 i}+\beta_{9} X_{9 i}+\beta_{10} X_{10 i} \\
& +\beta_{11} X_{11 i}+\beta_{12} X_{12 i}+\beta_{13} X_{13 i}+\beta_{14} X_{14 i}+\varepsilon_{i}
\end{aligned}
$$

where

$Y=$ Proportion of refills four times from among those who got LPG connection under PMUY.

$X_{1}=$ MGNREGA expenditure per capita (ratio of MGNREGA expenditure to state population).

$X_{2}=$ Square of MGNREGA expenditure per capita $\left(\mathrm{X}_{1}\right)$.

$X_{3}=$ Total rainfall in 2018 (in millimetre).

$X_{4}=$ Square of total rainfall in 2018 .

$X_{5}=$ Rural female literacy rate.

$X_{6}=$ Proportion of ST in rural population.

$X_{7}=$ Proportion of SC in the rural population.

$X_{8}=$ Female workforce participation rate.

$X_{9}=$ Male workforce participation rate.

$X_{10}=$ Per cent of rural population under the poverty line.

$X_{11}=$ Area under very dense forest (in hectare).

$X_{12}=$ Area under moderate dense forest (in hectare).

$X_{13}=$ Area of open forest (in hectare).

$X_{14}=$ Area under scrub (in hectare). 
$\varepsilon_{I}=$ Stochastic error.

We use Stata 15.1 "regress" command to estimate OLS results (see Table 13.2) and the post-estimation commands to confirm that the data fulfils the OLS assumptions to validate our estimated coefficients. We conducted three post-estimation tests for (1) normality, (2) heteroskedasticity and (3) influential observations. We found that for all three tests, the null hypothesis of normality, homoscedasticity and non-influential observations holds.

(1) Heteroskedasticity: We did a Breusch-Pagan test which has a chi-square value of 1.879 (with $p$-value: 0.170 ).

(2) Normality of residuals: We did a Shapiro-Wilk W normality test which has a " $z$ " value of 1.242 (with a $p$-value: 0.107 ).

(3) Influential observations: We did a Cook's distance test, which is less than 1.00, and there is no distance which is above the cut-off.

While most of these variables are used commonly as independent variables, the case of forests is not self-evident. LPG adoption is expected to reduce demand for wood fuel and therefore forest dependence. There are two points to be noted here. First, many researchers have noted that fuelwood use does not reduce the density and canopy cover of trees. The fuelwood demand for forest-dependent communities is met by loping of lower branches and dry wood. Second, the impact of fuel wood collection on forest quality is not necessarily dependent on access to the forest or the density of forest-dependent population but on the availability of wage labour and local markets (Davidar et al., 2010). Third, LPG adoption is unlikely to show results in the very short run and is more of a long-term intervention.

\subsection{Results}

The summary statistics of the above variables is presented (in Table 13.1) below. Our findings indicate that around $48 \%$ of all those who got an LPG connection reported refilling the LPG four times a year ranging from a low of $6 \%$ to a high of $92 \%$. The distribution nearly approximates a normal distribution (see Supplementary information, Graph S.G1). The average per capita expenditure on MGNREGA in 2017 was INR754. The reported average rainfall in 2018 in India was $1103 \mathrm{~mm}$, ranging from 804 to a high of $5065 \mathrm{~mm}$. The wide range in rainfall is a reminder of the 15 agro-climatic zones in the country. The heterogeneity is not just in geography, but also in social characteristics. Female literacy on average was $55 \%$ and varied between a low of $12 \%$ to a high of $89 \%$. The districts differed in terms of marginalized groups (SC and ST populations). While the average ST population was $19 \%$ (minimum 0 to a maximum of $99 \%$ ), the SC population on average was $16 \%$, with a smaller range of $1-53 \%$. The female workforce participation, which is an indicator of the presence of women in the paid workforce, had a national average of $32 \%$ (from a low of $5 \%$ to a high of $65 \%$ ). 
Table. 13.1 Summary statistics of variables

\begin{tabular}{l|l|l|l|l|l|l}
\hline Variable & Unit & Obs & Mean & Std. dev & Min & Max \\
\hline $\begin{array}{l}\text { Proportion of PMUY } \\
\text { beneficiaries who refilled } \\
\text { four times }\end{array}$ & Number & 610 & 47.74 & 17.67 & 5.92 & 91.53 \\
\hline $\begin{array}{l}\text { MNREGA expenditure per } \\
\text { capita }\end{array}$ & Rs. lakh (INR) & 597 & 0.008 & 0.01 & 0 & 0.11 \\
\hline Rainfall in 2018 & Mm & 577 & 1103.35 & 804.67 & 0 & 5065.9 \\
\hline Female literacy rate & $\%$ & 633 & 0.55 & 0.12 & 0.24 & 0.89 \\
\hline $\begin{array}{l}\text { Proportion of ST in rural } \\
\text { population }\end{array}$ & Number & 624 & 0.19 & 0.28 & 0 & 0.99 \\
\hline $\begin{array}{l}\text { Proportion of SC in rural } \\
\text { population }\end{array}$ & Number & 624 & 0.16 & 0.1 & 0 & 0.53 \\
\hline $\begin{array}{l}\text { Female workforce } \\
\text { participation rate (rural) }\end{array}$ & $\%$ & 624 & 32 & 13 & 5 & 65 \\
\hline Rural poverty rate & $\%$ & 509 & 28.25 & 19.71 & 0 & 88.4 \\
\hline Very dense forest & $\mathrm{Ha}$ & 634 & 156.31 & 407.51 & 0 & 4699.29 \\
\hline Moderately dense forest & $\mathrm{Ha}$ & 634 & 483.44 & 742.04 & 0 & 5881.18 \\
\hline Scrub forest & $\mathrm{Ha}$ & 633 & 72.52 & 159.91 & 0.26 & 1520.19 \\
\hline Open forest & $\mathrm{Ha}$ & 634 & 475.23 & 522.35 & 0 & 3538.63 \\
\hline
\end{tabular}

Source Authors' calculations from multiple sources

Variables influencing these refills were-MGNREGA expenditure, rainfall, female literacy, the proportion of SC and ST populations, female workforce participation rate, percentage of poor in a district, extent of density of forest, prevalence of open and scrub forests (see Table 13.2). Female literacy rate, the proportion of SC population, as well as prevalence of very dense forest and scrub forest, influence the refills positively. On the other hand, the proportion of the ST population, female workforce participation and percentage of poor and open forest negatively impact refills. The negative relation with female workforce participation may seem odd because the greater this value the more likely it is to have greater family income, and therefore potentially a cause for LPG adaption. However, we are aware that the official statistics on female workforce participation may be underreporting the value. A large proportion in the female rural workforce may not be part of the paid workforce but participate in productive activity. This could be a possible reason for this result.

There is a nonlinear relationship between refills and its two determinants, MGNREGA and rainfall (U-shaped). Both of these variables influence the income of rural households. An initial increase in MGNREGA expenditure or rainfall reduces refills. However, as these values-MGNREGA expenditure or rainfall (below a calamity level) - rise, the increased household income positively impacts on refills after a threshold level. It comes as no surprise that refills are low in areas of high poverty. 
Table. 13.2 Results of ordinary least squares regression (robust standard errors)
Dependent Variable: Proportion of PMUY beneficiaries who refilled four times

\begin{tabular}{|c|c|}
\hline Independent variables & Coefficient ( $t$-value) \\
\hline MNREGA expenditure per capita & $\begin{array}{l}-2677.2 * * * \\
(-7.03)\end{array}$ \\
\hline $\begin{array}{l}\text { Square of MNREGA expenditure per } \\
\text { capita }\end{array}$ & $\begin{array}{l}103,518.7 * * * \\
(-5.76)\end{array}$ \\
\hline Total rainfall in 2018 & $\begin{array}{l}-0.0094 * * * \\
(-3.66)\end{array}$ \\
\hline Square of total rainfall in 2018 & $\begin{array}{l}0.0000017 * * \\
(2.75)\end{array}$ \\
\hline Female literacy rate (rural) & $\begin{array}{l}13.34 * \\
(1.85)\end{array}$ \\
\hline Scheduled Caste population (rural) & $\begin{array}{l}12.75 * \\
(1.65)\end{array}$ \\
\hline Scheduled Tribe population (rural) & $\begin{array}{l}-20.79 * * * \\
(-4.84)\end{array}$ \\
\hline Workforce participation (male, rural) & $\begin{array}{l}1.17 \\
(0.07)\end{array}$ \\
\hline Workforce participation (female, rural) & $\begin{array}{l}-13.23 * * \\
(-1.99)\end{array}$ \\
\hline Very dense forest in 2019 & $\begin{array}{l}0.005^{*} \\
(2.41)\end{array}$ \\
\hline Moderately dense forest in 2019 & $\begin{array}{l}-0.0004 \\
(-0.29)\end{array}$ \\
\hline Open forest in 2019 & $\begin{array}{l}-0.004 * * \\
(-2.24)\end{array}$ \\
\hline Scrub area in 2019 & $\begin{array}{l}0.008 * * \\
(1.95)\end{array}$ \\
\hline Constant & $\begin{array}{l}65.2 * * * \\
(9.67)\end{array}$ \\
\hline $\mathrm{N}$ & 445 \\
\hline$R$-square & 0.4939 \\
\hline adjusted $R$-square & 0.4775 \\
\hline$F(14,430)$ & 29.98 \\
\hline Prob $>F$ & 0.0000 \\
\hline
\end{tabular}

Source Authors' calculations 
We have four measures of forest types - very dense, moderately dense, scrub and open. Refills are higher in areas with very dense forest and scrub areas. The reasons for this could be that in very dense forests fuelwood collection would be difficult and regulated by the forest department. Therefore, there is a higher adoption of alternate fuels. In scrub areas, there is a lower availability of fuelwood which, again, leads to a higher number of refills. However, in open forests, there is scope for fuelwood availability and so refills are less frequently observed.

Information on forest category indicates higher instances of refills in dense and scrub forests for reasons given above, the relationship with moderately dense shows as insignificant. In moderately dense forests, state monitoring is relatively less. There is also relatively greater availability of fallen branches and dry wood. Harvesting of fuelwood from this category of forests can be significant. However, this relationship needs to be more closely studied. Vidanage et al., (2022, Chap. 15 of this volume) and Devi et al., (2022, Chap. 8 of this volume) have shown that state support for programmes could elevate outcomes to being more sustainable.

\subsection{Conclusion and Policy Implications}

Today, about three-fifths of India's households rely on fuelwood and other solid fuels. Continuing these consumption patterns could lead to significant environmental impacts, especially considering India's high population growth and increasing fuelwood extraction. India will need to move away from fossil fuels gradually to meet sustainable development targets and carbon-mitigation targets. Increasing household LPG use is one of the several pathways to achieve this.

However, projections of the International Energy Outlook report suggest that in 2030, 580 million people in India will still be using traditional fuels and India would then fall short of its target under SDG 7 (Affordable and Clean Energy) (IEA, 2017). This is despite government efforts to improve access to subsidized connections through various schemes. The main reasons cited for this gap in meeting targets are poor implementation, supply shortage and lower affordability. While two of these issues need to be addressed from the supply side, this chapter focused on the push needed from the demand side to improve LPG uptake.

Our analysis indicates that poorer households are more likely to switch fuels if their disposable income increases through employment generation schemes. The expenditure on MGNREGA is a policy-determined variable, and the decision-makers could ensure a win-win situation of triggering the triple benefits of reduced household air pollution, reduction in forest dependence and reduced emission of carbon, in turn promoting affordable and clean energy (SDG 7) for rural households.

Switching to cleaner cooking fuels such as LPG has the potential to deliver extensive health, social and environmental benefits, including positively affecting climate in the short term (Bruce et al., 2017; Rosenthal et al., 2018; Singh et al., 2017). It can further support achieving a few of the targets under SDG. Since India is committed to achieving the Sustainable Development Goals by balancing economic, social and environmental goals, the wide use of LPG would be a small but sure step towards achieving these objectives. 


\section{References}

Bailis, R., Drigo, R., Ghilardi, A., \& Masera, O. (2015). The carbon footprint of traditional woodfuels. Nature Climate Change, 5(3), 266-272. https://doi.org/10.1038/nclimate2491

Bari, E., Haque, A. K. E., \& Khan, Z. K. (2022). Local strategies to build climate resilient communities in Bangladesh. In A. K. E. Haque, P. Mukhopadhyay, M. Nepal, \& M. R. Shammin (Eds.), Climate change and community resilience: Insights from South Asia (pp. 175-189). Springer.

Bhojvaid, V., Jeuland, M., Kar, A., Lewis, J., Pattanayak, S., Ramanathan, N., Ramanathan, V., \& Rehman, I. (2014). How do people in Rural India perceive improved stoves and clean fuel? Evidence from Uttar Pradesh and Uttarakhand. International Journal of Environmental Research and Public Health, 11(2), 1341-1358. https://doi.org/10.3390/ijerph110201341

Bisht, D. S., Sridhar, V., Mishra, A., Chatterjee, C., \& Raghuwanshi, N. S. (2019). Drought characterization over India under projected climate scenario. International Journal of Climatology, 39(4), 1889-1911. https://doi.org/10.1002/joc.5922

Bruce, N. G., Aunan, K., \& Rehfuess, E. A. (2017). Liquefied petroleum gas as a clean cooking fuel for developing countries: Implications for climate, forests, and affordability (Materials on development financing No. 7, pp. 44). KfW Development Bank. https://static1.squarespace.com/static/53856e1ee4b00c6f1fc1f602/t/5b16ec08352f 538a85f57d7c/1528228877332/2017_Liquid-Petroleum-Clean-Cooking_KfW.pdf

Census (2011). Primary census abstracts, Registrar General of India, Ministry of Home Affairs, Government of India. http://www.censusindia.gov.in

Chaudhuri, S., \& Gupta, N. (2009). Levels of living and poverty patterns: A district-wise analysis for India. Economic and Political Weekly, XLIV (9), 94-110.

Chung, C. E., Ramanathan, V., \& Decremer, D. (2012). Observationally constrained estimates of carbonaceous aerosol radiative forcing. Proceedings of the National Academy of Sciences, 109(29), 11624-11629. https://doi.org/10.1073/pnas.1203707109

Conibear, L., Butt, E. W., Knote, C., Arnold, S. R., \& Spracklen, D. V. (2018). Residential energy use emissions dominate health impacts from exposure to ambient particulate matter in India. Nature Communications, 9(1). https://doi.org/10.1038/s41467-018-02986-7

Dabadge, A., Sreenivas, A., \& Josey, A. (2018). What has the Pradhan Mantri Ujjwala Yojana achieved so far? Economic and Political Weekly, 53(20), 7-8. https://www.epw.in/journal/2018/ 20/notes/what-has-pradhan-mantri-ujjwala-yojana-achieved-so-far.html

Davidar, P., Sahoo, S., Mammen, P. C., Acharya, P., Puyravaud, J.-P., Arjunan, M., Garrigues, J. P., \& Roessingh, K. (2010). Assessing the extent and causes of forest degradation in India: Where do we stand? Biological Conservation, 143(12), 2937-2944. https://doi.org/10.1016/j.biocon.2010. 04.032

Deshpande, A. (2011). The grammar of caste: Economic discrimination in contemporary India. Oxford University Press.

Devi, P. I., Sam, A. S., \& Archana Raghavan Sathyan, A. R. (2022). Resilience to climate stresses in South India: Conservation responses and exploitative reactions. In A. K. E. Haque, P. Mukhopadhyay, M. Nepal, \& M. R. Shammin (Eds.), Climate change and community resilience: Insights from South Asia (pp. 113-127). Springer.

FSI. (2011). Carbon stock in India's Forests. Forest Survey of India, Ministry of Environment and Forest. http://fsi.nic.in/carbon_stock/

FSI. (2019). State of forest report 2019. Forest Survey of India, Ministry of Environment, Forests and Climate Change.

Giri, A., \& Aadil, A. (2018). Pradhan Mantri UjjwalaYojana:A demand-side diagnosticstudy of LPG refills (Policy Brief). Microsave Consulting Services. http://www.microsave.net/wp-content/ uploads/2018/11/Pradhan_Mantri_Ujjwala_Yojana_A_demand_side_diagnostic.pdf

Gadgil, S., \& Gadgil, S. (2006). The Indian Monsoon, GDP and Agriculture. Economic and Political Weekly, 41(47), 4887-4895. JSTOR. https://www.jstor.org/stable/4418949

Gould, C. F., \& Urpelainen, J. (2018). LPG as a clean cooking fuel: Adoption, use, and impact in rural India. Energy Policy, 122, 395-408. https://doi.org/10.1016/j.enpol.2018.07.042 
IEA. (2016). World energy outlook 2016. IEA. https://www.iea.org/reports/world-energy-outlook2016

IEA. (2017). World Energy Outlook 2017. IEA, Paris. https://www.iea.org/reports/world-energyoutlook-2017

IMD. (2015). All India district rainfall statistics: India meteorological department. Government of India. https://mausam.imd.gov.in/imd_latest/contents/rainfallinformation.php

IMD. (2016). All India District Rainfall Statistics: India Meteorological Department. Government of India. https://mausam.imd.gov.in/imd_latest/contents/rainfallinformation.php

IMD. (2017). All India District Rainfall Statistics: India Meteorological Department. Government of India. https://mausam.imd.gov.in/imd_latest/contents/rainfallinformation.php

IMD. (2018). All India district rainfall statistics: India meteorological department. Government of India. https://mausam.imd.gov.in/imd_latest/contents/rainfallinformation.php

IPCC. (2007). Climate change 2007: Synthesis report. Intergovernmental Panel on Climate Change.

IPCC. (2014). The IPCC's fifth assessment report what's in it for South Asia? Overseas Development Institute and Climate and Development Knowledge Network. https://cdkn.org/wp-content/upl oads/2014/04/IPCC_AR5_CDKN_Whats_in_it_for_South_Asia_FULL.pdf

IPCC. (2018). Global warming of $1.5^{\circ} \mathrm{C}$ (E-edition). Intergovernmental Panel on Climate Change. http://www.ipcc.ch/report/sr15/

Jain, A., Tripathi, S., Mani, S., Patnaik, S., Shahidi, T., \& Ganesan, K. (2018). Access to clean cooking energy and electricity: Survey of states 2018. CEEW, Council on Energy, Environment and Water. https://www.ceew.in/sites/default/files/CEEW-Access-to-Clean-Cooking-Ene rgy-and-Electricity-11Jan19_0.pdf

Jeuland, M. A., \& Pattanayak, S. K. (2012). Benefits and costs of improved cookstoves: Assessing the implications of variability in health, forest and climate impacts. PLOS ONE, 7(2), e30338. https://doi.org/10.1371/journal.pone.0030338

Kankaria, A., Nongkynrih, B., \& Gupta, S. K. (2014). Indoor air pollution in India: Implications on health and its control. Indian Journal of Community Medicine, 39(4), 203. https://doi.org/10. 4103/0970-0218.143019

Kar, A., Pachauri, S., Bailis, R., \& Zerriffi, H. (2019). Using sales data to assess cooking gas adoption and the impact of India's Ujjwala programme in rural Karnataka. Nature Energy, 4(9), 806-814. https://doi.org/10.1038/s41560-019-0429-8

Khandker, S. R., Barnes, D. F., \& Samad, H. A. (2012). Are the energy poor also income poor? Evidence from India. Energy Policy, 47, 1-12. https://doi.org/10.1016/j.enpol.2012.02.028

Krishna Kumar, K., Rupa Kumar, K., Ashrit, R. G., Deshpande, N. R., \& Hansen, J. W. (2004). Climate impacts on Indian agriculture. International Journal of Climatology, 24(11), 1375-1393. https://doi.org/10.1002/joc.1081

Kumar, P., Dhand, A., Tabak, R. G., Brownson, R. C., \& Yadama, G. N. (2017). Adoption and sustained use of cleaner cooking fuels in rural India: A case control study protocol to understand household, network, and organizational drivers. Archives of Public Health, 75(1). https://doi.org/ 10.1186/s13690-017-0244-2

Mani, S., Jain, A., Tripathi, S., \& Gould, C. F. (2020). Sustained LPG use requires progress on broader development outcomes. Nature Energy, 5(6), 430-431. https://doi.org/10.1038/s41560020-0635-4

Pandey, D. (2002). Fuelwood studies in India: Myth and reality. Center for International Forestry Research.

PMUY. (2018). State-wise PMUY refill profile for the connections installed till 31.12 .2018 since beginning (May, 2016) and refill upto 03.06.2019. Pradhan Mantri Ujjwala Yojana, Ministry of Petroleum and Natural Gas Government of India. https://pmuy.gov.in/registereduser.html

PPAC. (2018). Consumption of petroleum products. Petroleum Planning and Analysis Cell, Ministry of Petroleum and Natural Gas, Government of India. https://www.ppac.gov.in/content/147_1_C onsumptionPetroleum.aspx 
PPAC. (2019). Energizing and empowering India: Annual report 2018-19. Petroleum Planning and Analysis Cell, Ministry of Petroleum and Natural Gas, Government of India. http://petroleum. nic.in/sites/default/files/AR_2018-19.pdf

Rosenthal, J., Quinn, A., Grieshop, A. P., Pillarisetti, A., \& Glass, R. I. (2018). Clean cooking and the SDGs: Integrated analytical approaches to guide energy interventions for health and environment goals. Energy for Sustainable Development, 42, 152-159. https://doi.org/10.1016/ j.esd.2017.11.003

Sankhyayan, P., \& Dasgupta, S. (2019). 'Availability' and/or 'affordability': What matters in household energy access in India? Energy Policy, 131, 131-143. https://doi.org/10.1016/j.enpol.2019. 04.019

Sen, A. (2000). Development as freedom. Anchor Books.

Shammin, M. R., \& Haque, A. K. E. (2022). Small-scale solar solutions for energy resilience in Bangladesh. In A. K. E. Haque, P. Mukhopadhyay, M. Nepal, \& M. R. Shammin (Eds.), Climate change and community resilience: Insights from South Asia (pp. 205-224). Springer.

Singh, D., Pachauri, S., \& Zerriffi, H. (2017). Environmental payoffs of LPG cooking in India. Environmental Research Letters, 12(11), 115003. https://doi.org/10.1088/1748-9326/aa909d

Smith, K. R. (2000). National burden of disease in India from indoor air pollution. Proceedings of the National Academy of Sciences, 97(24), 13286-13293. https://doi.org/10.1073/pnas.97.24. 13286

Smith, K. R., \& Sagar, A. (2014). Making the clean available: Escaping India's Chulha trap. Energy Policy, 75, 410-414. https://doi.org/10.1016/j.enpol.2014.09.024

UNFCCC. (2018). INDC-Submissions. United Nations. http://www4.unfecc.int/Submissions/ INDC/Submission\%20Pages/submissions.aspx

University Of East Anglia Climatic Research Unit (CRU), Harris, I. C., \& Jones, P. D. (2019). CRU TS4.03: Climatic research unit (CRU) time-series (TS) version 4.03 of high-resolution gridded data of month-by-month variation in climate (Jan. 1901-Dec. 2018) [Application/xml]. Centre for Environmental Data Analysis (CEDA). https://doi.org/10.5285/10D3E3640F004C5784034 19AAC167D82

Van Leeuwen, R., Evans, A., \& Hyseni, B. (2017). Increasing the use of liquefied petroleum gas in cooking in developing countries (World Bank Other Operational Studies No. 26569). The World Bank. https://econpapers.repec.org/paper/wbkwboper/26569.htm

Vidanage, S. P., Kotagama, H. B., \& Dunusinghe, P. M. (2022). Sri Lanka's small tank cascade systems: Building agricultural resilience in the Dry Zone. In A. K. E. Haque, P. Mukhopadhyay, M. Nepal, \& M. R. Shammin (Eds.), Climate change and community resilience: Insights from South Asia (pp. 225-235). Springer.

Walker, M. (2005). Amartya Sen's capability approach and education. Educational Action Research, 13(1), 103-110. https://doi.org/10.1080/09650790500200279 
Open Access This chapter is licensed under the terms of the Creative Commons AttributionNonCommercial-NoDerivatives 4.0 International License (http://creativecommons.org/licenses/bync-nd/4.0/), which permits any noncommercial use, sharing, distribution and reproduction in any medium or format, as long as you give appropriate credit to the original author(s) and the source, provide a link to the Creative Commons licence and indicate if you modified the licensed material. You do not have permission under this licence to share adapted material derived from this chapter or parts of it.

The images or other third party material in this chapter are included in the chapter's Creative Commons licence, unless indicated otherwise in a credit line to the material. If material is not included in the chapter's Creative Commons licence and your intended use is not permitted by statutory regulation or exceeds the permitted use, you will need to obtain permission directly from the copyright holder.

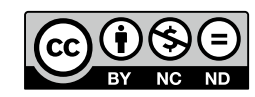

